\title{
Helicobacter Phytotherapy: Medicinal Plants Affecting H. pylori Infection in Iran
}

\author{
Negin Farhad ${ }^{1}$, Somayeh Shahsavari ${ }^{*}$
}

${ }^{1}$ Department of Chemistry, Islamic Azad University, Khorramabad Branch, Khorramabad, Iran

${ }^{2}$ Razi Herbal Medicines Research Center, Lorestan University of Medical Sciences, Khorramabad, Iran

${ }^{3}$ Department of Environmental Health, Food Safety Division, Faculty of Public Health, Tehran University of Medical Sciences, Tehran, Iran

\section{*Correspondence to:}

Somayeh Shahsavari

m.pirhadi371@gmail.com

Received: 26 June 2020

Accepted: 1 Novamber 2020

ePublished: 27 Novamber 2020

Keywords: Infectious Diseases, Helicobacter pylori, Medicinal plants, Antibacterial compounds, Iran

\section{Citation:}

Salahvarzi S, Shakib P, Pirhadi M, Alikord M, Jahed Khaniki GHR. Helicobacter Phytotherapy: Medicinal Plants Affecting $H$. pylori Infection in Iran. Plant Biotechnol Persa 2020; 2(2): 38-23.

Abstract
$\begin{aligned} & \text { Helicobacter pylori is a gram-negative, helical, and microaerophilic bacterium, and its in- } \\ & \text { fection affects the health of the community. This bacterium protects itself from stomach } \\ & \text { acid by having the enzyme urease. Nearly three decades after the discovery of this bacteri- } \\ & \text { um, no specific treatment regimen has been proposed that is able to eliminate the infection } \\ & \text { in patients. Besides, the different treatment regimens with different effects on the pathogen } \\ & \text { have been proposed. Widespread use of antibiotics and medicinal plants in treatment and } \\ & \text { eradication has led to the growth of antibiotic resistance. In this review study, the most im- } \\ & \text { portant medicinal plants with inhibitory effect on H. pylori were reported. For this review } \\ & \text { study, keywords such as H. pylori bacterial infection, medicinal plants, extract and Iran } \\ & \text { were used. The databases searched for in those articles were Google Scholar, SID, Scapus, } \\ & \text { PabMed, Science Direct, and ISI search engines. Plants such as Satureia hortensis L., Sal- } \\ & \text { via officinalis, Mentha Piperita, Ziziphora tenuior, Mentha pulegium, Satureja khuzestanica, } \\ & \text { Thymus caramanicus, Thymus vulgaris, Zataria multiflora, Ocimum basilicum L, Salvia mir- } \\ & \text { zayanii, Teucus frutus, Majus frutics, Rubus frutics, Geum Iranicum, Filipendula ulmaria L, } \\ & \text { Glycyrrhiza glabra L., Citrus sinensis, Argentin anserine, Bunium persicum, Crataegus aronia, } \\ & \text { Cuminum cyminum L. and etc. were assessed. These are the most important medicinal } \\ & \text { plants affecting on H. pylori in Iran. }\end{aligned}$

\section{Introduction}

Helicobacter pylori is a gram-negative, helical and microaerophilic bacterium (1). H. pylori infection is affected by the health status of the community so that it has a high prevalence in third world countries such as Iran (2). It protects itself from acidic conditions of the stomach with the enzyme urease (3). The prevalence of this infection in Iran has been reported in adults up to $90 \%$. Its prevalence is up to $80 \%$ in developing countries and from 30 to $40 \%$ in developed countries $(4,5)$. H. pylori plays an important role in the development of gastrointestinal diseases such as chronic gastritis, adenocarcinoma, lymphoma and peptic ulcer of the stomach $(6,7)$. About three decades after the discovery of this bacterium, no specific treatment regimen has been proposed that can eliminate the infection in all treated patients, and different treatment regimens with different effects on the pathogen have been proposed (8). Extensive use of antibiotics in treatment and eradication has led to an increase in antibiotic resistance $(9,10)$. Medicinal plants are a valuable source of active medicinal substances that affect a variety of disorders and diseases $(11,12)$. Various studies have shown that herbal and medicine plants have an inhibitory effect on $\mathrm{H}$. pylori $(13,14)$. In this review study, the most important medicinal plants with inhibitory effect on H.pylori were reported.

\section{Method for review}

For this review study, keywords such as H. pylori, bacterial infection, medici-

Copyright (C) 2020 The Author(s). This is an open-access article distributed under the terms of the Creative Commons Attribution License (http://creativecommons.org/licenses/by/4.0), which permits unrestricted use, distribution, and reproduction in any medium, provided the original work is properly cited. 
nal plants, extract and Iran were used. The databases searched for in those articles were Google Scholar, SID, Scopus, PubMed, Science Direct, and ISI.Results Medicinal plants as an anti-H. Pylori $H$. pylori can cause a wide range of problems, from chronic gastritis, peptic ulcer disease, iron deficiency anemia and stomach cancer to diseases of the liver, cardiovascular system, skin and many other systems of the body. No vaccine has been developed for this infection so far, and treatments for it include the use of chemical drugs and herbs.

Table 1. Medicinal plants used as anti-H. Pylori in Iran 